\title{
Fertiliser, Plant Nutrient Management, and Self-reliance in Agriculture
}

\author{
NiSAR AHMAD and TILA MUHAMMAD
}

\section{INTRODUCTION}

The importance of agriculture in the economy of Pakistan is well established. Agricultural plays an important role both directly and indirectly in generating economic activity, growth and development. Agriculture has strong backward and forward linkages and is vital to the food security of the country. Fertilisers have played an important role in Pakistan agriculture particularly in meeting the growing demand for food grains, fibre, fuel and fodder. Fertiliser consumption has increased during the last four decades to 2.6 million tonnes by 1997-98. The use level is, however, not only sub optimal but also imbalanced. Better plant nutrient management is, therefore, necessary for achieving self reliance in agriculture.

\section{FARMING AS AN OCCUPATION}

Farming is probably the oldest profession and has been practiced in our society since time immemorial. Agriculture is not only a means of livelihood but a way of life of the majority of people in Pakistan. Presently more than 60 percent of total population is living in the rural areas and are directly or indirectly dependant upon agriculture. This high engagement of population in agriculture and related activities highlight the importance of agriculture and farming in economic well being of the people. It also emphasises the fact that the economic well being of the people heavily depends on proper and sound development of agriculture. Pakistan is and will remain an agricultural country for quite a long time in the future. With the increase in the human requirement for different necessities of life, there will be a corresponding increase in the dependence of farm population on agriculture. As such, farming is and will play an important role in the lives of rural population.

Nisar Ahmad and Tila Muhammad are currently working as Chief/Project Director and Deputy Chief (Policy Planning), respectively, in the National Fertiliser Development Centre, Planning and Development Division, Government of Pakistan, Islamabad.

Authors' Note: We are thankful to the Pakistan Society of Development Economists (PSDE) for providing them an opportunity to present a paper in the 14th Annual General Meeting and Conference. We also wish to acknowledge the support and encouragement of our colleagues in NFDC for their assistance in the preparation of the paper and for providing reference material. We also extend our gratitude to the authors of the material cited and apologise for any omission in this respect. 


\section{FRAGILE FOOD SECURITY}

According to census of 1997, the population of Pakistan is 130.579 million. Despite expected slow down in population growth in future it is estimated that population will reach 164.0 million by 2010 (Planning and Development Division, 1999). Total food consumption has grown faster and per capita food consumption, as measured by calories consumed, has risen from 2,301 calories per day in 1979-80 to 2,532 calories in 1996-97 [FAO (1996)].

Wheat is the most important food item and accounts for 50 percent of total calories and 85 percent of total protein intake. An FAO study on National Agricultural Development Horizon-2010 (1996) indicates that by the year 2010, per caput food demand would rise to 3,055 calories per day. The proteins intake would reach 80 gms by 2010. This would be accompanied by a change in the composition of food demand-demand for cereals would fall while demand for higher value food stuffs such as livestock products, vegetables, pulses and vegetable oils would rise. Despite these shifts, wheat would continue to play a key role, contributing 40 percent of total calories intake. This goes to show that the consumption pattern in Pakistan is shifting towards products associated with general increase in income.

The food situation in Pakistan had always been fragile. The demand for food especially for wheat, which is the main staple food, had often over-stripped the domestic supplies. Notwithstanding, the fact that food grains production in 1997-98 had reached 24.8 million tonnes i.e. $180 \mathrm{kgs} / \mathrm{caput} / \mathrm{year}$, the food security problem in Pakistan continues to remain acute in the wake of explosive rise in demand.

Domestic production of wheat met only 80 percent of requirements and some 2 to 3.5 million tonnes of wheat were imported annually in 1992 to 1997 . About 4 million tonnes of rice are also produced of which nearly one million tonne, mostly high quality basmati rice, is exported. Maize and other course grains are produced annually around 3 million tonnes [Pakistan (1997)]. Important non-cereal foods include vegetable oils and sugar, each of which accounts for around 12 percent of total calorie intake and milk which accounts for around 9 percent [FAO (1996)].

The cropped area in the last decade has increased from 20.90 million ha to 22.93 million ha at the rate of 0.93 percent per annum. This has been achieved due to expansion in availability of irrigation water, mostly through ground water resources and on farm water management. Assuming that in future area expansion will be at the rate of 0.5 percent per annum, the total available cropped area will be close to 24.4 million ha by 2010. On the other hand, the per capita cropped area will decline from the current $0.16 \mathrm{ha} /$ capita to $0.13 \mathrm{ha} / \mathrm{capita}$. As such, the future growth in agriculture will largely depend on increasing productivity per unit of land which in turn would depend on plant nutrient management. 


\section{WORLD FERTILISER USE AND FOOD GRAIN PRODUCTION}

Global fertiliser use increased from 26 million tonnes in 1958 to 145 million tonnes by 1988. Political and economical upheaval and reforms in Eastern Europe and former Soviet Union beginning in 1988, has, however, led to a temporary reduction in over all global fertiliser use. Consequently, global consumption fell to 121 million tonnes by 1993 before recovering to 136 million tonnes in 1997-98. Of 136 million tonnes of inorganic fertilisers used in 1997-98, 81 million tonnes (59 percent of total world consumption) was nitrogenous fertilisers, 33.0 million tonnes (24 percent) phosphatic fertilisers and 22 million tonnes (16 percent) potassium fertilisers. The share of developing countries is estimated at 56 percent [Soh and Isherwood (1998)].

Global grain production in 1997-98 was 1911 million tonnes. Of this 53 percent was produced by developing countries and 47 percent by developed world. Global consumption in 1997-98 was 1877 thousand tonnes. Developing countries consumed 59 percent compared to 41 percent of developed world. Wheat production in 1997-98 surpassed 600 million tonnes for the first time. Global grain utilisation in 1998-99 is forecast to reach 1890 million tonnes (+0.7 percent). The increase for 1996 and 1997 were 1.3 percent and 2.9 percent, respectively. The slower increase in utilisation is attributed to lower growth in feed use, particularly in developed countries. Due to three successful years of good harvest global grain stocks are projected within secure range of 17 to 18 percent stock to consumption in 1998-99. Grain prices, particularly maize and wheat have been drifting downward since their peaks in May 1966 and showed slight recovery recently [Soh and Isherwood (1998) and FAO (1998)].

\section{FERTILISER NUTRIENT USE AND FOOD GRAIN PRODUCTION IN PAKISTAN}

Consumption of fertilisers which was about 382 thousand tonnes $(43.0 \mathrm{~kg}$ $\left.\mathrm{ha}^{-1}\right)$ in 1971-72, has reached a level of about 2.6 million tonnes $\left(116 \mathrm{~kg} \mathrm{ha}^{-1}\right)$ in 1997-98. However, there is a wide variability in the consumption pattern in the four provinces (Table 1). Fertiliser use in Sindh province is highest followed by Punjab, NWFP and Balochistan. Cotton production region in Punjab consumes over one third of all the fertiliser used in the country. Second most important crop production region is mixed cropping system in Punjab, which consumes almost quarter of the total. Thus these two crop production regions in Punjab account for almost 60 percent of the total fertiliser consumption in the country. Cotton belt of Sindh and mixed crop production region in NWFP also consume

significantly higher levels. The crop production regions of Balochistan are the smallest consumer in the country. 
Table 1

Average Nutrient Use Rate $\mathrm{Kg} \mathrm{ha}^{-1}$ and N:P Ratios in 1997-98

\begin{tabular}{lrccrc}
\hline Province & \multicolumn{1}{c}{$\mathrm{N}$} & $\mathrm{P}_{2} \mathrm{O}_{5}$ & $\mathrm{~K}_{2} \mathrm{O}$ & Total & N:P Ratio \\
\hline Punjab & 87.3 & 24.7 & 1.2 & 113.2 & 3.5 \\
Sindh & 136.8 & 30.1 & 0.3 & 167.2 & 4.5 \\
NWFP & 59.2 & 14.4 & 0.3 & 73.8 & 4.1 \\
Balochistan & 38.3 & 10.9 & 0.2 & 49.4 & 3.5 \\
Pakistan & 91.0 & 24.0 & 0.9 & 116.0 & 3.8 \\
\hline
\end{tabular}

Source: Fertiliser Annual Review 1997-98, NFDC.

Food grain production and fertiliser consumption statistics indicate that food grain production more than doubled from 10.6 million tonnes to 24.8 million tonnes between 1971-72 and 1997-98. In the corresponding period fertiliser use increased by about seven times. However, the fertiliser consumption was imbalanced. Consumption of fertiliser nutrients and N:P:K ratios since 1971-72 are shown in Table 2.

Although, fertiliser application rates and nutrient source vary from field to field, the N:P ratio of 2:1 is considered agronomically acceptable on a macro scale. It should be fully recognised that the fertiliser rates are different for irrigated, dry land, and horticultural crops. Moreover, fertiliser consumption pattern also depends on the organic nutrient sources available to farmers. The use of potash and micronutrients is also equally important in deficit soils and on specific crops. However, large deviation from an N:P use ratio of 2:1 will make fertiliser use imbalanced. This raises the serious question of maintaining the soil fertility for sustainable crop production.

Table 2

Fertiliser Consumption, NPK Use Ratio and Food Production in Pakistan

\begin{tabular}{|c|c|c|c|c|c|c|c|c|}
\hline \multirow[b]{2}{*}{ Year } & \multicolumn{4}{|c|}{ Fertiliser Nutrient Consumption ('000 t) } & \multirow{2}{*}{\multicolumn{3}{|c|}{$\mathrm{N}: \mathrm{P}_{2} \mathrm{O}_{5}: \mathrm{K}_{2} \mathrm{O}$ Ratios }} & \multirow{2}{*}{$\begin{array}{c}\text { Food Grain } \\
\text { Production '000 t }\end{array}$} \\
\hline & $\mathrm{N}$ & $\mathrm{P}_{2} \mathrm{O}_{5}$ & $\mathrm{~K}_{2} \mathrm{O}$ & NPK & & & & \\
\hline $1971-72$ & 343.97 & 37.23 & 0.74 & 381.94 & 1 & 0.11 & 0.002 & 10632 \\
\hline $1976-77$ & 510.99 & 117.94 & 2.36 & 631.29 & 1 & 0.23 & 0.005 & 13341 \\
\hline 1981-82 & 830.55 & 225.19 & 21.74 & 1077.48 & 1 & 0.27 & 0.026 & 16319 \\
\hline $1986-87$ & 1332.5 & 408.87 & 42.51 & 1783.88 & 1 & 0.31 & 0.032 & 18082 \\
\hline 1991-92 & 1462.62 & 398.01 & 23.3 & 1883.93 & 1 & 0.27 & 0.016 & 20634 \\
\hline $1996-97$ & 1985.08 & 419.47 & 8.43 & 2412.98 & 1 & 0.21 & 0.004 & 22750 \\
\hline 1997-98 & 2087.61 & 551.28 & 20.44 & 2659.33 & 1 & 0.26 & 0.010 & 24808 \\
\hline
\end{tabular}

Sources: Pakistan (1997, 1998); National Fertiliser Development Centre (1998). 


\section{CROP RESPONSE AND ECONOMICS OF FERTILISER USE}

\section{Yield Response to Fertilisers}

The single most important factor that affects the demand for fertiliser is the crops response to different levels of input; while there is a positive economic response the farmer has incentive to use additional inputs. Generally, different combinations and rates of fertilisers are tried to determine economic yields. The Provincial Soil Fertility Institutes and other Research Organisations in the country have generated data relating to crop yields with different nutrient combinations, mainly through simple trials in the farmers fields. The National Fertiliser Development Centre has collated the data from these trials and derived quadratic equations for different crops. The following equation was derived for wheat crop, using the experimental data for the period 1992-96.

$$
Y=1417+14.0 \mathrm{~N}-0.41 \mathrm{~N}^{2}+9.2 \mathrm{P}_{2} \mathrm{O}_{5}-0.029\left(\mathrm{P}_{2} \mathrm{O}_{5}\right)^{2}+0.0362 \mathrm{~N} \times \mathrm{P}_{2} \mathrm{O}_{5}
$$

These trials are closer to average farmer's conditions. The sites chosen are on reasonably good land mostly free from salinity and water-logging. Therefore, the above response equation shows slightly high intercept. However, using the coefficients, the response of NP will average around $10 \mathrm{~kg}$ of grain per $\mathrm{kg}$ of applied nutrient.

NFDC conducted a nation-wide survey on fertiliser use on wheat (Fertiliser Use on Wheat, 1996). The survey data delivered a response equation as follows:

$$
Y=993+10.01 N P K-0.013(N P K)
$$

The intercept in survey data is lower than that obtained from farmers' fields. There was a very wide scatter of the data. Nevertheless, the response of wheat to applied fertilisers is closed to $10 \mathrm{~kg}$ of grain per $\mathrm{kg}$ of applied nutrient.

An illustration of the wheat yield response to fertiliser application on irrigated wheat in Pakistan is presented in Figure 1, which is based on the results of 101 demonstrations conducted under farmers conditions in various wheat growing areas. It may be seen that there is a clear incremental response of wheat yield to fertiliser use. Especially, when fertiliser is used in a balanced manner, the yield responds in a corresponding manner. In case of only $\mathrm{N}$ application of $120 \mathrm{~kg} / \mathrm{ha}$, there is a net increase of $1027 \mathrm{~kg}$ of wheat, thereby contributing 8.5 $\mathrm{kg}$ wheat per $\mathrm{kg}$ of $\mathrm{N}$ application (Table 3). Similarly, when all the three nutrients i.e. N, P and K are used, the yield increases from $1515 \mathrm{~kg} / \mathrm{ha}$ to 3986 $\mathrm{kg} / \mathrm{ha}$. 


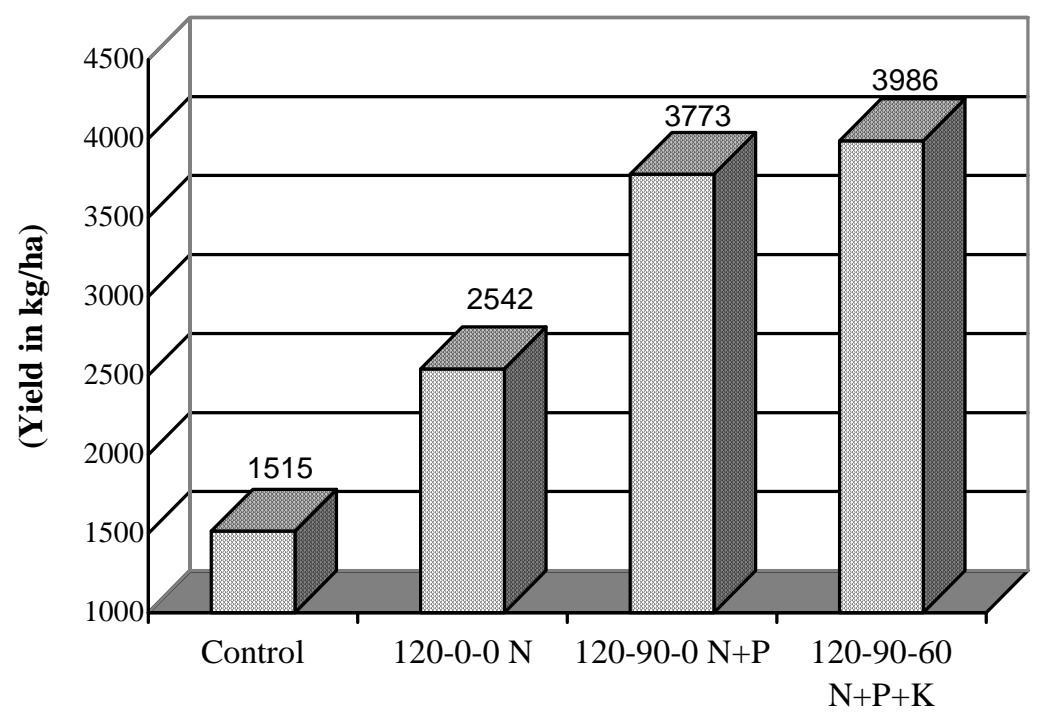

Fig. 1. Wheat Yield Response to Fertilisers.

Table 3

Economics of Fertiliser Use on Irrigated Wheat

\begin{tabular}{|c|c|c|c|c|c|c|c|c|c|c|}
\hline \multicolumn{3}{|c|}{ Fertiliser Rate } & Yield & $\begin{array}{c}\text { Increase } \\
\text { Yield } \\
\end{array}$ & $\begin{array}{l}\text { Gross } \\
\text { Return }\end{array}$ & $\begin{array}{c}\text { Net } \\
\text { Return }\end{array}$ & \multirow[b]{2}{*}{ VCR } & \multicolumn{3}{|c|}{ GNR } \\
\hline$\overline{\mathrm{N}}$ & $\mathrm{P}_{2} \mathrm{O}_{5}$ & $\overline{\mathrm{K}_{2} 0}$ & \multicolumn{2}{|c|}{ Kg/ha } & \multicolumn{2}{|c|}{ Rs/ha } & & $\mathrm{N}$ & $\mathrm{P}_{2} \mathrm{O}_{5}$ & $\mathrm{~K}_{2} \mathrm{O}$ \\
\hline 0 & 0 & 0 & 1515 & - & - & - & - & - & - & - \\
\hline 120 & 0 & 0 & 2542 & 1027 & 6162 & 4242 & 2.2 & 8.5 & - & - \\
\hline 120 & 90 & 0 & 3773 & 2258 & 13548 & 9468 & 2.3 & 8.5 & 13.6 & - \\
\hline 120 & 90 & 60 & 3986 & 2471 & 14826 & 9426 & 1.7 & 8.5 & 13.6 & 3.5 \\
\hline
\end{tabular}

\section{Economics of Fertiliser Use}

The economics of fertiliser use is an important parameter determining the profitability of fertiliser use. The use of fertiliser is justified only if it makes an economic sense besides contributing to the physical output of a particular crop. Since fertiliser is an expensive input, its efficient use is important from an economic 
point of view. A rational farmer will always consider the profitability of fertiliser before its use. It is, however, important that fertiliser is used in such a manner that it not only provides physical efficiency but also enhances financial profit on its application to various crops. Two important parameters i.e. the price of fertiliser and the price of crop produce determine the profitability of fertiliser use. However, if a proper balance is struck between these parameters, profitability could be maximised.

Despite their relatively higher prices, fertiliser use in Pakistan is still profitable on many crops. Wheat is generally considered to be an unprofitable crop from commercial point of view. Nevertheless, fertiliser use on wheat (irrigated) is profitable considering even the present unbalanced use pattern.

The financial return of fertiliser use is given in Table 3. It may be seen that in case of only N, there is a net return of Rs 4242/ha from irrigated wheat. When P is added, the net return increases to Rs 9468/ha and there is a further increase due to inclusion of $\mathrm{K}$ in the application rate. Although, the value cost ratio (VCR) slightly decreases when fertiliser use becomes more balanced, yet the net profit almost doubles. It is thus imperative that farmers are induced to use fertiliser in a balanced manner not only to maximise their physical output but also to increase financial return on fertiliser use. Nevertheless, since profitability depends on the relative prices of fertilisers, it is equally necessary that the input and output prices are administered in such a manner as to allow the most economical use of the important input.

\section{STRUCTURAL ADJUSTMENT PROGRAMME AND FERTILISER USE DEVELOPMENT}

Structural adjustment programmes have been instituted in many countries including Pakistan at the behest of IMF and World Banks with the long term goal of reallocating resources, so as to improve economic efficiency and social welfare. The programmes have included reforming exchange rate, fiscal, monetary and trade policies, as well as promoting liberalisation, the withdrawal of subsidies and privatisation of state owned enterprises.

In Pakistan fertiliser sector, government intervention was of two types. Subsidy on sale of fertilisers and government involvement in the production, import and distribution of fertilisers. Subsidies on sale of fertilisers encouraged fertiliser use by reducing the costs to farmers, acted as safeguard against exponential price increase of imported fertilisers due to increasing international prices and exchange rate devaluation. It was considered a means of import substitution for agricultural commodities to achieve national food security through inducing farmers to produce more by using cheaper inputs. The opponents by contrast argued that subsidies strain foreign exchange reserves and government budgets, lead to market imperfections, which prevent the farmers to obtain good products at right time and at competitive price. 
The reforms in fertiliser sector were initiated by mid 1980's. Subsidy on nitrogenous fertilisers was abolished in 1986. Phosphate prices were deregulated in 1993 and potash in 1995. Moreover, imports and marketing of all fertilisers was liberalised and quota system of fertiliser allocation for the provinces was also abolished. Favourable fertiliser policy was pursued which facilitated new investment by among other things, exempting plant, machinery and equipment as well as raw materials from import duties, ensured gas supply at reduced price and assuring a floor price for DAP. The policy also envisaged equal treatment of public and private sector plants with respect to entitlement to concessions.

Since initiation of reforms in 1986-87, urea production has increased from 1.2 million tonnes to 4.2 million tonnes in 1998-99. The first DAP plant of 450 thousand tonnes has been commissioned in the country. Private sector has entered in the import of fertilisers and its share in 1997-98 was 45.0 percent.

However, fertiliser consumption suffered a setback after deregulation of prices (Table 4). The growth in nitrogen consumption of 10.0 percent per annum in pre deregulation period slowed down to 2.0 percent after deregulation during the period from 1987-88 to 1991-92. Phosphate consumption declined at the rate of 0.5 percent per annum during the same time frame. Phosphate prices also increased due to partial elimination of subsidy as DAP/urea price ratio increased sharply from 1.0 to 1.7 during 1985-86 to 1991-92 (Table 5). Nitrogen consumption picked up since 1992-93 and is maintaining a rate of 5.0 percent per annum, where as phosphate consumption showed long periods of stagnation from 1987-88 to 199192 (average 390 thousand tonne) and from 1993-94 to 1996-97 (phosphate consumption declined from 488 thousand tonnes to 420 thousand tonnes). The year 1997-98 showed recovery (consumption 550 thousand tonnes) but consumption will decline sharply during 1998-99.

Table 4

Growth Rates (\%) of Fertiliser Nutrients Before and After Deregulation Period

\begin{tabular}{lcccc}
\hline Period & $\mathrm{N}$ & $\mathrm{P}$ & $\mathrm{K}$ & Total \\
\hline 1982-83 - 86-87 & 9.9 & 12.7 & 14.4 & 10.6 \\
$1987-88-91-92$ & 2.0 & -0.5 & -11.3 & 1.1 \\
$1982-93-96-97$ & 6.3 & 1.0 & -19.2 & 5.0 \\
8th Plan & 5.0 & 2.46 & -3.21 & 4.37 \\
\hline
\end{tabular}


Table 5

Urea and DAP International and Farm-gate Prices in Pakistan

\begin{tabular}{|c|c|c|c|c|c|}
\hline \multirow[b]{2}{*}{ Year } & \multicolumn{2}{|c|}{ Urea US $\$ / t$} & \multicolumn{2}{|c|}{ DAP US $\$ / t$} & \multirow{2}{*}{$\begin{array}{c}\text { DAP/Urea Price } \\
\text { Ratio at Farm } \\
\text { Gate }\end{array}$} \\
\hline & International & Farm Gate & International & $\overline{\text { Farm Gate }}$ & \\
\hline$\overline{1985-86}$ & 87 & 158 & 177 & 165 & 1.0 \\
\hline 1988-89 & 131 & 140 & 194 & 195 & 1.4 \\
\hline 1991-92 & 141 & 117 & 161 & 201 & 1.7 \\
\hline 1994-95 & 187 & 152 & 192 & 253 & 1.7 \\
\hline 1997-98 & 105 & 152 & 200 & 251 & 1.7 \\
\hline 1998-99 & 75 & 140 & 210 & 280 & 2.0 \\
\hline
\end{tabular}

\section{FACTORS CONSTRAINING IMPROVED CROP PRODUCTION}

\section{General}

There are many factors limiting agricultural progress but the outstanding one is the shortage of irrigation water. The water availability at farm gate from canals is about 93 million acre feet. Groundwater underlies the plains, about 60 percent in the CCA being sweet, 11percent being marginal and 28 percent saline. About 46 MAF are withdrawn by tubewells and the recharge is nearly of the same magnitude, so there is no scope for further withdrawals. New tubewells will continue to be sunk, however, and this will have the effect of lowering the water table in sweet water areas, resulting in inflow of saline water. Canal water is subject to severe losses, estimated over 40.0 percent, while conveyance losses of tubewell water are 7 percent. In the field, due to the flooding system in use, 28 percent of water reaching the field is lost through evaporation and leaching. It is crucial that more efficient methods of water conservation and use are introduced soonest. Unirrigated agriculture in Pakistan has much lower potential than irrigated, due to uncertainty and insufficiency of water. Agriculture can be broadly classified into four types; (i) rainfed agriculture, (ii) cropping in hill-torrent areas (this has extremely low potential), (iii) dry farming in very dry areas by water harvesting and (iv) cropping in the active flood plains of the rivers (islands in the stream and on river edges). Agriculture in all such areas is further hampered by poverty and lack of supplies. Soil erosion is another serious problem, which should be properly addressed.

Other general constraints to crop improvement include poor farm implements, poor quality seed and low seed rate, late sowing of crops, poor weed control, waterlogging and salinity and inadequate pest and disease control measures. There are also deficiencies in efficient plant nutrient knowledge and advice; the extension services are very weak and many farmers are illiterate. Availability of some fertilisers is poor; 
inadequate at right time and at right quantity. There are no micronutrients except for some zinc sulphate. Farmers have limited financial resources and especially for small farmers, fertiliser price rises are difficult to accommodate. Farmers therefore tend to over-purchase cheaper urea and under-purchase expensive DAP and SOP. Another constraint is land fragmentation; some fragments are impossible to farm at all and it makes good management difficult. Tenancy, although declining, robs the farmer of any incentive to look beyond the current crop.

\section{Crop-specific}

There are also several crop-specific constraints. In wheat, these are low profitability, prolonged canal closures, late sowing and weeds. For cotton, they are low and unbalanced use of fertiliser, cotton leaf curl virus (there is a possible link with imbalanced fertiliser), low plant population, insect resistance to insecticides, rains at planting time, adulterated fertilisers and pesticides, and diversion of water to sugarcane areas. In rice, zinc deficiency and the problems in overcoming it, as well as its antagonism with phosphate inefficient methods of applying urea, haphazard planting and low plant population, poor pest and disease control are the main limitations. For sugarcane, inability to time water applications correctly and highly imbalanced use of fertiliser, unsuitable planting time and poor ratoon management are severe problems. Maize yields are limited by poor varietal potential, much barani planting, windstorms and bird and wild boar predation. Oilseeds and pulses receive low management standards, vegetables suffer from lack of packing/processing facilities and poor roads; fruits are rarely fertilised or sprayed adequately [Twyford et al. (1995)].

\section{ROLE OF IMPROVED PLANT NUTRITION IN ACHIEVING CROP REQUIREMENTS}

There is incontrovertible evidence, from farmers' own yield results, that crop yields can be considerably increased above present levels through improved crop nutrition. If other limiting factors are alleviated also, crop yields will benefit further. Nutritional improvements include, in steps:

- improved $\mathrm{N}: \mathrm{P}_{2} \mathrm{O}_{5}$ ratio;

- introduction and use of micronutrients and potash;

- proper integration of biological practices with fertilisers; and

- improved techniques like fertigation.

From the data of fertiliser use surveys [Fertiliser Use Surveys of NFDC (1986, 1987, 1992)] among farmers it has been found that much higher than average crop yields are being achieved by varying proportions of farmers, nearly always those 
who are practising crop nutrition nearer to recommendation, at least for $\mathrm{N}$ and $\mathrm{P}_{2} \mathrm{O}_{5}$.

For irrigated wheat, survey showed 34 percent of farmers reaching yields of 3,000 to $5,900 \mathrm{~kg} / \mathrm{ha}$, mostly those who applied $90-180 \mathrm{~kg} / \mathrm{ha} \mathrm{N}$ and 57-60 kg/ha $\mathrm{P}_{2} \mathrm{O}_{5}$.

For barani wheat, yields of best farmers in surveys ranged from 2,000 to $4,500 \mathrm{~kg} / \mathrm{ha}$, after use of $80 \mathrm{~kg} / \mathrm{ha} \mathrm{N}$ and $28-56 \mathrm{~kg} / \mathrm{ha} \mathrm{P}_{2} \mathrm{O}_{5}$.

In rice, 1992 case study, yields in the Punjab, the problem area, for good farmers were IRRI, 4.1 to 6.6 t/ha paddy and for basmati 4.2-4.7 t/ha paddy. High IRRI yields were obtained after using high $\mathrm{N}$ and $\mathrm{P}_{2} \mathrm{O}_{5}$. In surveys, IRRI rice yields rose to $6.3 \mathrm{t} /$ ha and over 15 percent of farmers achieved $4,000 \mathrm{~kg} / \mathrm{ha}$ or more. High survey basmati yields were 2,500-3,500 kg/ha. All these farmers use adequate level of nitrogen and phosphate.

The maize yields of good farmers in surveys were above $3,500 \mathrm{~kg} / \mathrm{ha}$ for irrigated and 2,500 kg/ha for barani. Moderately high levels of $\mathrm{N}$ and $\mathrm{P}_{2} \mathrm{O}_{5}$ promoted such yields, and FYM helped further.

In sugarcane, survey data showed over 10 percent of farmers achieving 100$140 \mathrm{t} / \mathrm{ha}$, and a few reached $200 \mathrm{t} / \mathrm{ha}$. These farmers were applying up to $140 \mathrm{~kg} / \mathrm{ha}$ $\mathrm{P}_{2} \mathrm{O}_{5}$ as well as abundant $\mathrm{N}$ and FYM. Few farmers used potash however, which could have raised yields further.

Similar observations have been made for cotton, although in that crop, there is a very wide variation of yield depending on pest control efficiency.

A notable point is that research has shown that high crop yields can be achieved by moderate rates of balanced (NPK) fertiliser, similar to those produced from high rates of $\mathrm{N}$, with or without some $\mathrm{P}_{2} \mathrm{O}_{5}$ or potash and micronutrients where deficient. Further, the yield performance on the best farms is usually not far different from research yields after using recommended rates of NPK. The scope for overall yield improvement is therefore considerable.

\section{ENVIRONMENTAL ISSUES AND SOIL DEGRADATION}

The over supply of nutrients from inorganic and organic sources in excess of plant needs and poor farm management practices can lead to some environmental problems. Soil nitrate concentration in excess of plant absorption need can leach down in ground water that can contaminate surface waters and underground aquifire. Leaching and run off of nitrogen and phosphorus promotes algael over production in water reservoirs which may damage the marine environment. When in excess of plant needs nitrogen also escapes into the atmosphere as nitrogen gas and various nitrite oxides. Although fertiliser nutrient applications are necessary for plant growth, to maintain soil fertility and to sustain agriculture over the long term, overuse is wasteful as it does not increase crop yields and contributes to environmental damage. Fertiliser should therefore be applied at the recommended levels by adopting proper technology and best management practices at farm level. 
While over application of fertilisers can contribute to environmental issues in developed countries, under application/imbalance use and the decline of traditional soil fertility management practices, by contrast have contributed to mining of soils and thus their degradation in developing countries. Population induced food needs are such that land can no longer be taken out of production for substantial period of time to allow for natural process to replenish nutrients, nor is the incorporation of the crop residues and animal manures sufficient to rebuild soil nutrient. This has led to substantial nutrient mining of the soil [Gruhn et al. (1998)]. Nutrient mining of nitrogen, phosphate, potassium, sulphur, magnesium and micronutrients in Pakistan is estimated higher than that replenished through organic and inorganic sources. The nutrient depletion in Pakistan has been estimated as negative, nitrogen at $9 \mathrm{~kg}$ per hectare, $\mathrm{P}_{2} \mathrm{O}_{5} 11 \mathrm{~kg}$ per hectare and $\mathrm{K}_{2} \mathrm{O}$ $26 \mathrm{~kg}$ per hectare [FAO (1998)]. Thus, in future, continued nutrient mining will put the sustainability of agriculture in danger.

\section{FUTURE CHALLENGES AND INTEGRATED PLANT NUTRITION MANAGEMENT}

\section{Fertiliser Use}

The increased application of inorganic fertiliser is necessary to sustain a growth level of over 5 percent per annum in agriculture. Because of expected population growth, and the resultant food requirements, fertiliser demand is projected to increase by 5 percent per annum in the 9th Five Year Plan. The consumption of phosphate and potash shall grow faster than nitrogen to achieve the agronomic optimum mix for the crops. The deficiencies of secondary and micronutrients will also emerge in different crop production regions and will require due attention to sustain crop growth. However, the application of inorganic fertilisers alone will not be sufficient. As noted previously, excess application of crop nutrients can pose environmental problems. Moreover, inorganic NPK fertilisers do not replace secondary and other micronutrients removed by harvested crops, nor do they directly improve soil organic matter content and structure. For agriculture to be sustainable, integrated approach towards the management of plant nutrients will be necessary, in which inorganic nutrient application should be used as a supplement to other nutrient conservation and augmentation practices.

\section{Integrated Plant Nutrient Management (IPNM)}

Integrated plant nutrient management (IPNM) is an important component of sustainable agricultural intensification. IPNM centres on the management of soils in their capacity to be a storehouse of nutrients that are essential for plant growth. The goal of IPNM is to integrate the use of all natural and man-made sources of plant 
nutrients so as to increase crop productivity in an efficient and environment friendly manner [FAO (1998)].

IPNM incorporates nitrogen fixation and organic and inorganic fertiliser application. Organic fertilisers play an important role in the improvement of soil structure and organic matter content. They are also often a good source of the secondary and micro-nutrients necessary for plant growth and contribute a modest quantity of the primary nutrients (nitrogen, phosphorus, and potassium) to the soil. Biological nitrogen-fixation by leguminous plants and by cereals, whereby bacterianodules on the roots of the plants synthesise nitrogen for the plant, offer the future potential for plants themselves to meet some of their nutrient needs. Inorganic fertilisers are most desirable and effective when application coincides with the major growth spurts of the plant when the primary nutrients are needed most intensively and where necessary to make up for secondary and tertiary nutrient deficiencies in the soil [Gruhn et al. (1998)]. Further, by enhancing crop growth, inorganic fertiliser application has the added benefit of increasing the biomass of crop residues, which can in turn be reincorporated into the soil as a green manure to improve the structure and organic matter content of the soil. Nutrient application from organic and inorganic sources should thus be at the absolute and relative level required for optimal crop growth and yield, taking into account crop needs, soil nutrient balances, agro-climatic considerations, and improved soil characteristics, while minimising negative externalities.

Long term field experiments at the Rothamsted Experimental Station in England and at Research Institutes in Pakistan have provided a wealth of information on the yields of crops grown continuously and in rotation using a variety of soil fertility combinations. Substantial increases in wheat yields were only possible on organic and inorganic fertilised fields.

The choice for sustaining agriculture in the future is not simply using either inorganic fertiliser or organic fertiliser as these are not substitutes but complement each other. It is the synergy created by using the most appropriate mix of these technologies that will help to sustain agriculture. Effective and efficient management of these resources and technologies by farmers, specifically through integrated plant nutrient management practices, will help make it possible [Ahmad (1996)].

\section{Knowledge and Technology}

Knowledge coupled with technology is the key for farmers to manage soil fertility to produce more per unit of land. First, farmers need to know the condition of their soils. Widespread soil testing needs to be undertaken to gather data on the nutrient cycle and nutrient balances in representative areas. Second, once the condition of the soil is known, farmers can then select the most appropriate mix of technologies to manage soils and yields in the short and long-term, while minimising environmental externalities and taking into account their particular financial and 
resource circumstances. Here, researchers and extension services have a role to play in making farmers aware of the various technology options and their relative cost and effectiveness. Through their interaction with farmers, extension workers have the opportunity to learn and evaluate traditional soil management techniques and have the responsibility to disseminate the knowledge about the most cost effective and nutritionally beneficial practices for a particular farmer's situation in a variety of regions.

\section{POLICY RECOMMENDATIONS}

The soils of Pakistan are being continuously mined of essential plant nutrients through crop intensification. The deficit between nutrient supply and removal may increase further if appropriate steps are not taken. In order to bridge the gap, the country has to place sufficient, emphasise on use of inorganic fertilisers alongwith togethers with the use of organic and, bio fertiliser materials, the role of legumes in cropping system also needs be emphasised. The future of productive and sustainable agriculture in Pakistan largely depends on adopting more balanced use of fertilisers and their increasing efficiency. There is no need for concern about environmental degradation at the current level of fertiliser use. Technology incentives have to be suitably supportive and policy intervention should promote the balanced and judicious use of fertiliser materials to narrow the widening $\mathrm{N}: \mathrm{P}_{2} \mathrm{O}_{5}: \mathrm{K}_{2} \mathrm{O}$ ratios.

Efficient fertiliser and water management practices must be widely adopted for ensuring sustainability of agriculture in Pakistan. For the major production systems integrated plant nutrient supply and management systems must be developed, demonstrated and propagated. Research on fertiliser use efficiency should aim at refining fertiliser use practices, which promote better responses together with the maintenance of soil fertility. Government policies on promoting fertiliser use must ensure their sustained use through pricing policy on fertilisers and agricultural produce that makes their use economically viable. The timely availability of right type of fertilisers should be ensured to farmers and regulatory measures should be implemented to ensure the provision of quality fertiliser to the farmers.

\section{REFERENCES}

Ahmad, N. (1996) Current Use and Requirement for Sustainable Food Production in Pakistan. In A. E. Johnston and J. K. Syers (eds) (1998) Proc. Nutrient Management of Sustainable Crop Production in Asia. London: CAB. International.

FAO (1996) Strategy for National Agricultural Development: Harizon-2010. World Food Summit Follow-up, Rome.

FAO (1998) Plant Nutrition for Sustainable Agricultural Development in Pakistan. Field Document-I. Main Report, FAO, Rome. 
Gruhn, P., F. Goletti, and R. N. Roy (1998) Plant Nutrition Management, Food Security and Sustainable Agriculture. The Future Through 2020. Proc. IFPRI/FAO Workshop. Viterbo, Italy.

National Fertiliser Development Centre (1992) Fertiliser Use on Wheat, Farm Level Survey. Islamabad. (NFDC Publication No.5/96.)

National Fertiliser Development Centre (1998) Fertiliser Review. Islamabad: NFDC.

National Fertiliser Development Centre (1998) Pakistan Fertiliser Statistics. Islamabad: NFDC.

Pakistan, Government of (1987) Agricultural Statistics of Pakistan. Islamabad: Ministry of Food, Agriculture and Livestock.

Pakistan, Government of (1998) Economic Survey. Islamabad: Finance Division, Economic Advisor's Wing.

Pakistan, Government of (1999) Population Projections Pakistan (1998-2013). Planning and Development Division, Islamabad.

Soh, K. G., and K. F. Isherwood (1998) Prospects for World Agriculture and Fertiliser Use. 24th IFA Council Meeting, New Delhi.

Twyford, I. T., M. Sadiq, and M. G. Chaudhry (1995) Plant Nutrition Policies and Strategies for Sustainable Agriculture. FAO/NFDC, Ist Approximation Report. 